\title{
Vietnamese Farmers That Changed the World: the Impact of the Vietnam War on the Cold War
}

\author{
By: Michael Martignago
}

The Vietnam War was the quintessential Cold War conflict between the United States and the Sino-Soviet supplied, nationalistic North Vietnamese. This war saw the world's most wealthy and dominant military force suffer a long, drawn out defeat to a poverty-stricken society of farmers, armed with nothing but unyielding nationalism and outdated weaponry.

This paper examines the United States' involvement in Vietnam throughout the Vietnam War and also explores the ways in which the Vietnam War affected the Cold War. Beginning with President Harry S. Truman in 1945 and ending with President Gerald Ford in 1975, this paper examines the motivations behind each of the six United States Presidential Administrations during the Vietnam War and gives an in-depth explanation for the crucial decisions that were made by the United States Government over the course of the war. The effect that these foreign policy decisions and directives had on the Cold War atmosphere is also heavily analysed. The faults and failures of the United States that led to their humiliating defeat in Vietnam consequently altered the Cold War atmosphere. In order to fully understand the Cold War, it is necessary to understand the Vietnam War and its impact on United States foreign policy.

The Vietnam War was the longest war in American history, beginning with the United States' involvement in the French Colonial struggle during the early 1950s and ending with the tragic and humiliating fall of Saigon in April 1975. The United States was involved in Vietnam under leadership from six different Presidential 
Administrations, and, because of the length of the war, many aspects of the Cold War changed as the conflict in Vietnam progressed and escalated. The war continued, although through significantly different approaches. Beginning with President Harry S. Truman, the United States began supplying the French colonial forces in the southern half of Vietnam with military aid in $1950 .{ }^{1}$ The war became significantly more meaningful and closer to the hearts of Americans when President Lyndon B. Johnson escalated the conflict by authorizing the deployment of American ground troops in Vietnam in 1965. President Richard Nixon ushered in a new era of the Cold War with Détente and attempted to bring diplomacy to the forefront of the Vietnam War. However, he was unsuccessful in putting a concrete end to the Vietnam War before he was forced to resign due to domestic scandal. Finally, the conflict ended with President Gerald Ford declaring the end of the Vietnam War, and the last Americans were evacuated from the rooftops of the American embassy in South Vietnam. ${ }^{2}$

The Cold War atmosphere that was present when the Vietnam War first began in the early 1950s was vastly different than the Cold War atmosphere when the Vietnam War came to an end in the spring of 1975 . The Cold War dynamically evolved over the course of the two decade long conflict. Although there were six changes of Commander in Chief in the United States during the Vietnam War, there were similar key features that all the Presidential Administrations shared, as well as major differences in how each Administration went about fighting the war in Vietnam. This essay aims to answer the question, how was the Cold War impacted by the Vietnam War? The Vietnam War impacted the Cold War by provoking change in United States foreign policy, altering the

\footnotetext{
${ }^{1}$ Mark Atwood Lawrence, The Vietnam War: A Concise International History (New York: Oxford University Press, 2008), 40.

${ }^{2}$ Ibid, 167.
} 
Cold War atmosphere, and by creating dissent across American society, and the globe, against the United States government's involvement in Vietnam, consequently initiating the rise of anti-war peace protests and the counterculture of the 1960s and 1970s. United States foreign policy went through tremendous change over the course of the Vietnam War and experienced considerable adjustments in the years following the American defeat in Vietnam. These changes made to United States foreign policy as a result of the Vietnam War were crucial to the remainder of the Cold War. Alongside United States foreign policy, the Vietnam War impacted the Cold War atmosphere globally. The conflict scarred the view the rest of the world had of the United States. America's hegemony seemed to be slipping away after the Vietnam War, and the Soviets were rapidly approaching parity with the United States with respect to their nuclear arsenals and strength. The Vietnam War effectively demonstrated the strength and resolve of Third World nations and showcased the rise of the Third global power in the formerly bilateral Cold War. Finally, as the Vietnam War continued throughout the 1960s, American citizens began to criticize their government on the decisions being made in Vietnam and dissent spread across the country and globe, igniting the anti-war movement across the Western world. The Vietnam War was a major Cold War conflict, and in order to understand the Cold War in its entirety, the Vietnam War must be analysed and explored with respect to United States foreign policy, the changing Cold War consensus, and the dissent against United States involvement in Vietnam.

For the United States, involvement in Vietnam began in 1950 with America pledging their support to the French colonial forces in their fight against the nationalistic 
Democratic Republic of Vietnam. ${ }^{3}$ The French war in Vietnam began shortly after the end of World War II when Japan surrendered and relinquished their control over southeast Asia. After Japan left, Vietnam found itself in a power vacuum. The French desired to regain colonial control of Vietnam and re-establish themselves as a world superpower following devastation and loss of global prestige in World War II. ${ }^{4}$ The French attempted to transform South Vietnam into an industrialized colony that would help restore economic prosperity to France. However, the gross mistreatment, harsh conditions, and suppression of national self-determination experienced by the Vietnamese at the hands of the French led the Vietnamese people to revolt against the French colonizers. Under the leadership of Ho Chi Minh, the people of Vietnam, facilitated by communist doctrine and beliefs, engaged in an almost decade long conflict with the French colonial forces that were occupying Vietnam from 1946-1954. ${ }^{5}$ A majority of the world criticized France for continuing their war with Vietnam, claiming that France was desperately clinging to an "outdated colonial mentality." However, Britain and the United States backed France in their colonial conquest in Indochina.

Before examining America's involvement in Vietnam, it is first important to understand what is meant by "the Cold War." Directly after World War II, the United States and the Soviet Union emerged as the dominant global superpowers. However, the United States was vastly superior to the Soviet Union during the years directly following World War II. Europe had been devastated by the effects of the war, and its nations were attempting to rebuild and regain control of society. It was clear that the United States and

\footnotetext{
${ }^{3}$ Ibid, 40.

${ }^{4}$ Ibid, 29.

${ }^{5}$ Ibid, 28.

${ }^{6}$ Ibid, 35 .
} 
the Soviet Union were the dominant global forces. The Soviet Union followed communism and its doctrine, whereas the United States subscribed to capitalism. When determining what would become of the post-World War II world, the Soviets and Americans came into constant conflict, with each side desiring the rest of the world to adhere to their respective ideologies. Americans had a deep hatred for communism, and Soviets had a deep hatred for capitalism. Ultimately, their ideologies had fundamental differences and were incompatible. The term "Cold War" came to be used to describe the bilateral ideological conflict between the communist Soviets and the capitalist Americans; it became a battle of East vs. West. The Americans feared that the spread of communism across the globe would limit their markets and ultimately bring down their capitalistic society. The consistent effort to subvert communism and protect capitalism formed the basis of American foreign policy for the entire Cold War, from 1945 to 1991. The term "Cold War atmosphere" or "Cold War dynamics" refers to the way that war was being fought, not necessarily physically, at a specific period of time. It refers to events and situations occurring in the conflict between the Soviets and the Americans at a specific time. For instance, in 1950, the Cold War atmosphere can be described by the following: America had been fighting the communists in Korea, who were supported by the Soviets and Chinese; the Soviets had recently successfully tested their own atomic bomb; America was in the midst of a Red Scare in the Hollywood film industry; and the United States was economically supporting the French colonial forces and the Bao Dai regime in Vietnam, while the Soviets and Chinese were supporting Ho Chi Minh and the Vietnamese communists. Everything that was occurring for both the United States and 
the Soviet Union affected the Cold War atmosphere. ${ }^{7}$ When the Korean War ended, the Cold War atmosphere changed; there was no longer the tension of physical war between the Soviets and the Americans. The Vietnam War drastically altered the Cold War atmosphere. As the largest, longest, and bloodiest conflict to take place during the Cold War, the Americans, Soviets, and Chinese all altered the Cold War atmosphere and, as a result, drastically changed how the Cold War was waged.

The Truman Administration was the first United States presidential administration to become involved in Vietnam, as his predecessor, President Franklin D. Roosevelt, had been strongly against French involvement in Vietnam and believed that Vietnam should have the right of self-determination. ${ }^{8}$ The Truman Administration, although themselves faced with the war in Korea, pledged their support to the French colonial forces by means of military equipment such as tanks, naval vessels, weapons, and other equipment required to wage war. Even while fighting their own war in Korea, the United States shouldered one third of the cost of the French war in Vietnam. ${ }^{9}$ Alongside their military investment in French forces, the United States also economically funded the Bao Dai government in the southern half of Vietnam as an attempt to discourage communist uprising in Vietnam. The United States was not the only global superpower to become invested in the French-Vietnamese conflict. The Soviet Union and newly formed Communist China began to intervene economically, militarily, and politically, with the Soviets in 1947 and the Chinese in January $1950 .{ }^{10}$ By the spring of 1950 , the bilateral Cold War had been forced into Vietnam, with the Communist Sino-Soviets supporting

\footnotetext{
${ }^{7}$ Ibid, 40 .

${ }^{8}$ Ibid, 29.

${ }^{9}$ Ibid, 40.

${ }^{10}$ Ibid, 36 .
} 
the Viet Minh and Ho Chi Minh and the Americans backing the French colonial forces and the Bao Dai regime. The United States primarily saw the Vietnam conflict as a Cold War battle against communism, whereas the French saw the conflict as a last hope for regaining and preserving their colonial power. However, on 7 May 1954, the French colonial forces, with American economic support, were conquered by the Viet Minh in the Battle of Dien Bien Phu which lasted fifty-five days. ${ }^{11}$ Although the Battle of Dien Bien Phu was not strategically detrimental to the war against the Viet Minh, psychologically the defeat foreshadowed France's future in Vietnam. The day after the Battle of Dien Bien Phu ended, a ceasefire was called and international talks regarding Vietnam began at the Geneva Accords. ${ }^{12}$ Vietnam was divided into the communist North Vietnam and non-communist South Vietnam, with the promise to hold democratic elections that would unify Vietnam. However, the United States did not follow through with this pledge for Vietnamese self-determination, and so began the two decade long American conflict in Vietnam.

According to Secretary of State Dean Acheson in a ministerial meeting in Paris on 8 May 1950, the United States did not believe that national independence or democratic evolution could possibly exist in a Soviet dominated area and thus believed they were required to aid the French and Bao Dai regime in order to combat communism and seek peace and democracy in Vietnam. ${ }^{13}$ Acheson clearly confirms the failure of the United States to see the nationalism in Vietnam behind the Viet Minh revolution and consequently places the blame on Soviet influence, therefore subsequently bringing the

\footnotetext{
${ }^{11}$ Ibid, 45.

${ }^{12}$ Ibid, 47.

${ }^{13}$ Dean Acheson, "Sponsoring French Colonialism (Acheson Statement Excerpt, May 8, 1950)," in Vietnam: History, Documents and Opinions on a Major World Crisis, ed. Marvin E. Gettleman (Greenwich CT: Fawcett Pub, 1965), 89.
} 
Cold War to Vietnam. American foreign policy historian and Cold War revisionist Gabriel Kolko supports the belief that the United States, by 1947, "had become wholly convinced that the Soviet Union was in some crucial manner guiding many of the political and social upheavals in the world that were in fact the outcome of poverty, colonialism, and oligarchies." ${ }^{14}$ The failure of the United States government to distinguish between nationalism and communism in Vietnam was arguably their greatest downfall in the entire Vietnam War.

In terms of United States foreign policy, it is important to examine what changes were made, but arguably it is more important to examine what remained constant between the six different Presidential Administrations over the course of the Vietnam War. With President Harry S. Truman, the American conflict in Vietnam holds its origins. President Truman authorized economic and military aid to be sent to assist the French colonial forces in Vietnam. Truman's Administration, as shown by Secretary of State Dean Acheson, followed the monolithic view of communism, which caused them to mistake nationalism for Soviet communist influence in Vietnam. This was the main driving factor for American presence in Vietnam. Although the Soviets and Chinese were supplying the Viet Minh, communism was not the primary motivation for the Vietnamese revolution. Part of the tension and ignorance of nationalism in Vietnam by the Truman Administration came from their fears of the Soviets' successful development of the atomic bomb in 1949, which the United States feared would be used as a diplomatic tool against them for their role in Third World conflicts. ${ }^{15}$ Another aspect of fear by the

\footnotetext{
${ }^{14}$ Gabriel Kolko, Anatomy of a War: Vietnam, the United States, and the Modern Historical Experience (New York: Pantheon Books, 1985), 77.

${ }^{15}$ William Appleman Williams et al, eds., America in Vietnam: A Documentary History (Garden City, NY: Anchor Press, 1985), 68.
} 
United States during the early 1950s was a result of the Korean War. From 1950 to 1953, the Truman Administration was directly involved militarily in the Korean War. The threat of the North Korean communist invasion of South Korea forced the United States to intervene militarily and deploy American ground troops to counter the communist invasion. With the Korean War still raging on during the early 1950s, the primary fear for the Truman Administration was that Vietnam would turn into a Korean War scenario. The United States government wanted to prevent a communist takeover of Vietnam, and this fear therefore validated NSC-68 and the United States to provide economic and military aid to the French forces fighting against the communist uprising in Vietnam. ${ }^{16}$ NSC-68 was a document drafted by the United States National Security Council in 1950 that recommended that the United States provide military aid to any nation under the threat of communism. The fear of another Korean War is something that did not remain exclusive to the Truman Administration, but continued to his successor. It was not only the fear of the communist uprising in Vietnam that warranted United States economic aid to Vietnam. The Truman Administration believed that Southeast Asia was crucial to Japan regaining economic stability post-World War II. According to United States diplomat William Butterworth in a State Department Memo from 1947, "I believe a strong case can be made for the fact that economic revival of Japan is dependent upon the economic revival of Asia as a whole and vice-versa." ${ }^{, 17}$ Butterworth believed that a "Far Eastern Marshall Plan" would provide the best result in stimulating Japan's economy, but

\footnotetext{
${ }^{16}$ National Security Council Report, "United States Objectives and Programs for National Security (April 14, 1950)," in America in Vietnam: A Documentary History, eds. William Appleman Williams et al (Garden City, NY.: Anchor Press, 1985), 71.

${ }^{17}$ William Butterworth, "State Department Memo on Far Eastern Marshall Plan," in America in Vietnam: A Documentary History, eds. William Appleman Williams et al (Garden City, NY: Anchor Press, 1985), 66.
} 
also to subvert communist uprisings in Asia. ${ }^{18}$ Although President Truman was only in office until 1953, the changes and precedents his Administration set consequently shaped the United States' role in Vietnam for the next two decades, dramatically altered the Cold War atmosphere, and set the stage for future Cold War conflict.

When President Dwight D. Eisenhower took office in 1953, the Korean War was still underway and continued for the next six months. However, following the end of the Korean War, the attention of the United States turned to Southeast Asia and Vietnam. Analogous to his predecessor, President Eisenhower and his Administration shared the monolithic view of communism and the determination to combat Sino-Soviet communist subversion across the globe aggressively. After the Geneva Accords in 1954 divided Vietnam into halves, the United States broke the agreement that prohibited the external involvement of foreign nations in Vietnamese politics. By breaking this agreement, the United States brought the Cold War directly to Vietnam. The Soviets did not sit back and allow the United States to imperialize the Vietnamese people like the French had previously. Vietnam became a Cold War proxy war between the United States and the Soviet Union, but also a nationalistic conflict for the Vietnamese people. The reasoning behind intervention in South Vietnam can be attributed to "The Domino Theory." The Eisenhower Administration coined the term "Domino Theory," which means, according to Secretary of State John Foster Dulles, that if communist forces were successful in unifying Vietnam under communism, the rest of Southeast Asia would soon fall to communism as well, like dominoes falling, and the United States would lose their sphere

\footnotetext{
${ }^{18}$ Ibid, 66.
} 
of influence in Southeast Asia entirely. ${ }^{19}$ The "Domino Theory" is what motivated the United States to pursue more aggressive intervention in Vietnam and remained a staple of United States foreign policy for the remainder of the Vietnam War. The underlying fear for the United States still remained communism. Understanding the idea of the "Domino Theory" makes it possible to understand the United States' foreign policy decisions, which were made to prevent the "dominoes" from falling. ${ }^{20}$ The Korean War was very influential in determining and setting United States foreign policy for the early years of the Vietnam War. President Eisenhower in his "Change for Peace" speech on 16 April 1953 claimed that the "Korean Armistice would be a fraud if it merely released aggressive armies for attack elsewhere. ${ }^{21}$ President Eisenhower was essentially stating that the results and lessons learned from the Korean War would be disgraced if the United States allowed a similar communist uprising to break out in Vietnam. This also reinforces the fact that the Eisenhower Administration, like the Truman Administration, wholeheartedly subscribed to the monolithic view of communism. They believed that the communists in North Korea followed the same doctrine and beliefs as the communists in North Vietnam. The United States government again completely disregarded the possibility that the revolution in Vietnam was mainly rooted in nationalism.

The Eisenhower Administration also initiated a drastic change regarding United States foreign policy in Vietnam. They aimed to create a robust, anti-communist South Vietnam, and, to accomplish this objective, the Eisenhower Administration created a

\footnotetext{
19 John Foster Dulles, "Speech to The Overseas Press Club (March 29, 1954)," in Vietnam: History, Documents and Opinions on a Major World Crisis, ed. Marvin E. Gettleman (Greenwich CT: Fawcett Pub, 1965), 90.

${ }^{20}$ Dwight D. Eisenhower, "Counting the Dominoes (Eisenhower Speech Excerpt April 7, 1954)" in America in Vietnam: A Documentary History, eds. William Appleman Williams et al (Garden City, NY: Anchor Press, 1985), 156.

${ }^{21}$ Dulles, "Speech to The Overseas Press Club (March 29, 1954)," 90.
} 
puppet regime in South Vietnam under the leadership of nationalist and vehement anticommunist Ngo Dinh Diem in $1954 .^{22}$ Diem was a devout Catholic, which immediately placed him in the small minority of the primarily Buddhist Vietnamese people. Placing Ngo Dinh Diem in the leadership role of South Vietnam turned out to be a major strategic failure for the United States. Diem was a corrupt leader, practising nepotism in his regime and further alienating the South Vietnamese peasants. Diem's regime and policies did more harm than good in their attempt to build up a strong anti-communist South Vietnam, infused with American ideology. Instead, Diem unintentionally fostered anti-American beliefs among the South Vietnamese lower-class which, in turn, led to an increased hatred of the United States by the Vietnamese people. ${ }^{23}$ The Eisenhower Administration's failure to foresee the Diem regime as being problematic and contradictory to what the United States had hoped to achieve is one of the major failures by the United States in the Vietnam War. The Eisenhower Administration failed to understand the nature of South Vietnamese society and failed to see the true wants and desires of the Vietnamese people due to their obsession with defeating the supposed communist threat.

President Eisenhower also cemented the Vietnam War as solely America's war with his failed recruiting of Winston Churchill and Britain through his 1954 letter to Churchill asking for the British to support the United States in their fight for Vietnam. Eisenhower reached out to Churchill personally, but Churchill declined to pledge Britain's support to the United States in Vietnam. ${ }^{24}$ Later on in the Vietnam War, Britain and other American allies including Canada, France, and West Germany all advised the

\footnotetext{
${ }^{22}$ Lawrence, 56.

23 Ibid, 61.

${ }^{24}$ Department of State, "Foreign Relations of the United States, 1952-1954, XIII, Indochina, Part 2," in America in Vietnam: A Documentary History, eds. William Appleman Williams et al (Garden City, NY: Anchor Press, 1985), 153.
} 
United States to stop the fighting and pull out of Vietnam. ${ }^{25}$ The United States foreign policy under Eisenhower revolved around training the South Vietnamese and assisting them so they could fight their own battle against the North Vietnamese. However, according to Vice-President Richard Nixon in a speech on 17 April 1954, "It is hoped the United States will not have to send troops there, but if this government cannot avoid it, the Administration must face up to the situation and dispatch forces. ${ }^{26}$ The Cold War atmosphere at this point was beginning to intensify. The Warsaw Pact had been established, and the Soviet sphere of influence in Eastern Europe was growing. The Cuban Revolution, led by Fidel Castro, had placed communists in "America's Backyard." Tensions were beginning to rise for the United States with respect to the Cold War. Although the Vietnam War was experiencing a period of "anguished peace" by 1959, the conflict in Vietnam began again as Ho Chi Minh declared war to unify Vietnam. ${ }^{27}$ The United States government under President Eisenhower set the stage for the Kennedy Administration and America's further involvement in Vietnam, with the continued monolithic view of communism and the installation of the Diem regime in South Vietnam.

When President John F. Kennedy took office in January 1961, the situation in Vietnam was a major concern. President Kennedy was victorious in the 1960 Presidential election, mainly due to his campaign promise that he would wage the Cold War far more vigorously than the Eisenhower Administration. ${ }^{28}$ By 1961, the Diem regime in Saigon was becoming more destabilized and facing far greater resistance from the Vietnamese

\footnotetext{
${ }^{25}$ Ibid, 153.

${ }^{26}$ Richard Nixon, "New York Times Speech (April 17, 1954)," in Vietnam: History, Documents and Opinions on a Major World Crisis, ed. Marvin E. Gettleman (Greenwich CT: Fawcett Pub, 1965), 91.

${ }^{27}$ Lawrence, 47.

${ }^{28}$ Ibid, 68 .
} 
people. President Kennedy and his Administration shared the consistent invariable view of communism, as did both of his predecessors. According to Kennedy's Secretary of Defense Robert McNamara, who, like most Americans, saw communism as monolithic, "I believed the Soviets and Chinese were cooperating in trying to extend their hegemony. In hindsight, of course, it is clear that they had no unified strategy after the late 1950s." ${ }^{29}$ This quote from Secretary McNamara provides incredible insight into the view of the United States government. They were so overcome with the fear and threat of communism that they were completely ignorant to the idea that communism was not uniform, but rather expressed in a variety of different forms, as seen in the Soviet Union, Red China, Korea, Cuba, and Vietnam.

With their underlying monolithic view of communism, the Kennedy Administration, according to McNamara, followed two primary foreign policy ideas. The first was a derivative of the "Domino Theory"; they believed that if South Vietnam fell to communism it would be a grave threat to the United States and to the Western nations. Secondly, the Kennedy Administration believed that the South Vietnamese were the only people who were capable of defending their own nation and that the United States was only able to play an advisory role. ${ }^{30}$ Although the Kennedy Administration subscribed to the monolithic view of communism, it is interesting that President Kennedy was able to compromise with communists in Laos in 1961, but was vehemently against compromise with the North Vietnamese communists. ${ }^{31}$ This hints that there was more than the

\footnotetext{
${ }^{29}$ Robert S. McNamara and Brian VanDeMark, In Retrospect: The Tragedy and Lessons of Vietnam (New York: Vintage Books, 1996), 30.

${ }^{30}$ Ibid, 29.

${ }^{31}$ Lawrence, 71.
} 
communist threat that was keeping the United States in the conflict in Vietnam, perhaps because Vietnam was a quintessential Cold War conflict, and Laos was not.

The Cold War atmosphere was about to reach a critical point. By the early 1960s the Cold War atmosphere was completely different from the previous decade. The Korean War was in the past. The nuclear arms race and the space race between the Soviets and the Americans was underway. The Cuban Missile Crisis in 1962 marked the closest the Cold War had come to a nuclear war. Both Ngo Dinh Diem and President Kennedy had been assassinated. The early 1960s were arguably the tensest years of the Cold War. The conflict in Vietnam dramatically raised the tensions primarily for the Americans, but also for the Soviets and Chinese as well. As the Cold War became more tense, the Vietnam War inched closer towards full-scale American intervention.

President Kennedy's outlook on the Vietnam War is confusing and somewhat contradictory. This is mostly because he was never able to finish his term as President due to his assassination in November 1963. In a National Security Action Memorandum on 13 November 1961, President Kennedy approved the recommendation that the Department of Defense should stand ready with plans that would authorize the use of American military forces in South Vietnam under one of three conditions. The first was the use of American forces to defend the South Vietnamese and to boost their morale; the second was the use of American forces to assist in the suppression of Vietcong insurgents in South Vietnam; and the third was the use of American forces to assist if there was a South Vietnamese communist military intervention in South Vietnam. ${ }^{32}$ This document provides evidence that President Kennedy and his Administration were planning for the

\footnotetext{
${ }^{32}$ National Security Action Memorandum, "Kennedy Administration Decisions in Vietnam (November 13, 1961)," in The Cold War: A History in Documents and Eyewitness Accounts, eds. Jussi Hanhimäki and Odd Arne Westad (London: Oxford University Press, 2003), 215.
} 
potential deployment of United States ground troops. However, to directly counter that claim, according to Secretary McNamara, the Kennedy Administration had been actively planning for "phased withdrawal of United States forces in 1963."33 McNamara claims that the Department of Defense had plans to withdraw one thousand men from Vietnam by the end of 1965 and that, according to United States foreign policy, these men were in Vietnam strictly as advisors. ${ }^{34}$ These two claims by the Kennedy Administration contradict each other. One claims that the Kennedy Administration was planning for deployment of the American military troops, and the other claims that the Kennedy Administration was planning for de-escalation and eventual withdrawal from Vietnam. Although there is no way of definitively proving which course of action President Kennedy ultimately would have taken, during his last statement made about Vietnam before his death, when asked "Are we going to give up South Vietnam?" President Kennedy responded "The most important program, of course, is our national security, but I don't want the United States to have to put troops there." ${ }^{35}$ Secretary McNamara believes that, had President Kennedy lived, he would have pulled the United States out of Vietnam. "He would have concluded that the South Vietnamese were incapable of defending themselves, and that Saigon's grave political weakness made it unwise to try to offset the limitations of the South Vietnamese forces by sending United States combat troops on a large scale. ${ }^{\not 36}$ However, it is important to remember that McNamara is speaking in retrospect and hypothetically. Like the Presidents before him, Kennedy and his Administration failed to see the nationalism behind the Vietnamese revolution and

\footnotetext{
${ }^{33}$ McNamara, In Retrospect, 29.

${ }^{34}$ Ibid, 79.

${ }^{35}$ Ibid, 86.

${ }^{36}$ Ibid, 96.
} 
attributed the entire conflict to communism. Examining the facts and not the hypotheticals, by the end of Kennedy's presidency, there were over 16,000 military advisors in South Vietnam. The Diem Regime had been overthrown in a military coup d'état, and Ngo Dinh Diem was murdered. By the end of 1963, South Vietnam was rapidly crumbling. Newly inaugurated President Lyndon B. Johnson was forced to take up the mantle and replace President Kennedy, while also dealing with the political power vacuum in South Vietnam that left the United States with not many options for dealing with the Vietnam War.

With the Johnson Administration, the Vietnam War drastically escalated. President Johnson shared many of the same goals for Vietnam as Kennedy and also shared a similar cabinet. President Johnson was thrust into a difficult position having to pick up where Kennedy left off with the crumbling South Vietnamese government. Johnson also had to prepare and campaign for the 1964 Presidential Election if he wanted to remain President. Johnson feared that any abrupt changes to United States foreign policy in Vietnam might be detrimental to the Presidential Election, so Johnson delayed on major foreign policy moves until after he had won the election. ${ }^{37}$ During the election, President Johnson aggressively and publicly denied that he had plans to escalate the war, while secretively considering escalation as the correct route to take United States foreign policy. ${ }^{38}$ Similar to his recent predecessors, Johnson followed the monolithic view of communism. The Johnson Administration desired an independent, free, non-communist South Vietnam. They believed that Vietnam must be free, but also able to accept

\footnotetext{
${ }^{37}$ Lawrence, 85.

${ }^{38}$ Williams et al, 239.
} 
American assistance to maintain security. ${ }^{39}$ The Johnson Administration believed in the "Domino Theory," and according to Secretary McNamara in a memo to President Johnson in 1964, "Unless we can achieve this objective in South Vietnam, almost all of Southeast Asia will probably fall under Communist dominance." ${ }^{40}$ The Johnson Administration initiated a major change in United States foreign policy when on 2 August 1964, the USS Maddox reported that the North Vietnamese had attacked with torpedoes in the Gulf of Tonkin. ${ }^{41}$ Following this incident, the United States Congress overwhelmingly passed the Gulf of Tonkin Resolution, which became the legal basis for the United States to be involved militarily in the Vietnam War. This resolution enabled President Johnson to circumvent Congress and allowed him to repel any attacks against the United States in South Vietnam by whatever measures were necessary. ${ }^{42}$ Johnson essentially used the Gulf of Tonkin Resolution to wage an undeclared war in Vietnam. Under President Johnson, American troops landed in South Vietnam, and they remained there for the next decade. United States foreign policy had rapidly shifted from Americans being advisors and military trainers to the South Vietnamese, to Americans fighting the war for the South Vietnamese. Not only were American ground troops in Vietnam, but President Johnson also authorized Operation Rolling Thunder in 1965, which was a massive scale bombing campaign that dropped over 600,000 tons of bombs on North Vietnam. ${ }^{43}$ Secretary McNamara contends that Congress never intended the

\footnotetext{
${ }^{39}$ Robert S. McNamara to Lyndon B. Johnson, "Memorandum entitled South Vietnam (March 16, 1964)" in America in Vietnam: A Documentary History, eds. William Appleman Williams et al (Garden City, NY: Anchor Press, 1985), 234.

${ }^{40}$ Ibid, 234.

${ }^{41}$ Lawrence, 86.

42 "The Gulf of Tonkin Resolution, 1964" in The Cold War: A History Through Documents, eds. Edward H. Judge, and John W. Langdon (Upper Saddle River, NJ: Prentice Hall, 1999), 135.

${ }^{43}$ Lawrence, 89.
} 
Gulf of Tonkin Resolution to be used in such a manner as President Johnson did. However, by the end of Johnson's Presidency, America was too far overextended and firmly entrenched in the Vietnam War. The monolithic view of communism had brought Americans into direct combat with the North Vietnamese. The decision to deploy ground troops to Vietnam had a monumental impact on the Cold War atmosphere. The Vietnam War was no longer a proxy war. Americans were directly involved in the combat, and American blood was being spilled by the Sino-Soviet supplied Vietcong. The Vietnam War became a quintessential, international Cold War conflict. It became a war that the United States was fighting singlehandedly, against the advice of their allies in North America and Europe; a war directly between the United States and the Communist Bloc. The Vietnam War also had the potential to go nuclear. According to Secretary McNamara in an off-the-record interview with the New York Times, he claims that the United States had not completely ruled out nuclear weapons and that the United States government agreed to only use nuclear weapons after completely exhausting their non-nuclear arsenal. ${ }^{44}$ Under President Johnson, the Vietnam War had become the primary conflict in the Cold War atmosphere, and the world's eyes were locked on what was happening in Vietnam.

President Richard Nixon was the first United States President to break the monolithic view of communism that had haunted and plagued the United States during the first three decades of the Cold War. According to President Nixon's National Security Advisor Henry Kissinger, the United States refused to leave Vietnam in a defeat by communism. However, Kissinger told Soviet Foreign Minister Andrei Gromyko in a

\footnotetext{
${ }^{44}$ Robert S. McNamara, "Off-the-Record Interview with Secretary of Defense McNamara by the New York Times (April 22, 1965)," in America in Vietnam: A Documentary History, eds. William Appleman Williams et al (Garden City, NY: Anchor Press, 1985), 247.
} 
meeting in Moscow in May 1972 that "We are prepared to leave so that communist victory is not excluded, though not guaranteed." 45 This essentially demonstrates that the United States still did not prefer communism in South Vietnam, but did not want to be viewed by the world as being "defeated" by communism. They were no longer as vehemently opposed to communism as the previous four Presidential administrations had been. The movement away from the monolithic view of communism by the Nixon administration comes during a time in the Cold War where the Soviet Union and the United States had reached a nuclear parity. ${ }^{46}$ The fear transitioned from communism to the Soviets themselves.

Nixon won the Presidential Election in 1968 and was inaugurated in January 1969. With the presidency came the daunting task of finding a way to de-escalate and end the Vietnam War, something that Nixon had promise during his campaign. ${ }^{47}$ Once Nixon took office, he slowly began to de-escalate the Vietnam War by lowering the number of American troops in Vietnam. ${ }^{48}$ The way Nixon hoped to end the war was through a peace deal with either the Soviets or the Chinese. Nixon's decision to openly acknowledge the People's Republic of China and open contact with the Chinese for the first time since their revolution in 1949 was motivated by his hope that China would be able to pressure North Vietnam into peace talks. ${ }^{49}$ The diplomatic recognition of China by Nixon drastically changed the Cold War. The war was no longer a bilateral conflict, and the

\footnotetext{
${ }^{45}$ Henry Kissinger-Andrei Gromyko, "Record of Conversation, 1972," in The Cold War: A History in Documents and Eyewitness Accounts, eds. Jussi Hanhimäki, and Odd Arne Westad (London: Oxford University Press, 2003), 230.

${ }^{46}$ Jussi Hanhimäki, "Conservative Goals, Revolutionary Outcomes: The Paradox of détente," Cold War History 8, no. 4 (2008): 506.

${ }^{47}$ Lawrence, 137.

${ }^{48}$ Richard Nixon, "Address to the Nation (23 January 1973)" in The Cold War: A History Through Documents, eds. Edward H. Judge, and John W. Langdon (Upper Saddle River, NJ: Prentice Hall, 1999), 166.

${ }^{49}$ Ibid, 166.
} 
Nixon Administration utilized this connection to China in attempts to set the Chinese and the Soviets against each other. ${ }^{50}$ China became a political tool for the United States to use against the Soviet Union.

In regard to the Cold War atmosphere, Vietnam was still a major focal point but with the introduction of Détente, the Cold War experienced a thaw, and the focus shifted away from conflict and towards negotiations and trade between the Soviet Union and the United States. The greatest change to United States foreign policy and the Cold War that occurred during the Vietnam War was Détente. Détente was the term used for the improving relations and the managing of conflict between the Cold War superpowers and the increased number of meetings and negotiations that took place between these powers. The Cold War superpowers were primarily focused on the signing of the Strategic Arms Limitation Treaty (SALT I) and the Anti-Ballistic Missile Treaty (ABM) which both were ways in which the Soviets and Americans agreed to limit and de-escalate their respective nuclear arsenals, which at the time were drastically increasing. ${ }^{51}$ Although both sides continued to pursue the same objectives as the earlier years of the Cold War, Détente was simply a new method employed by both sides in the Cold War. Détente arose as a strategy employed by the Nixon Administration to combat the Cold War through diplomacy, while simultaneously seeking an honourable exit from Vietnam. The Nixon Administration dramatically changed foreign policy in regards to Vietnam with the Nixon Doctrine in 1969. In this doctrine, Nixon proclaimed that the allied nations of the United States were responsible for their own security. However, the United States would

\footnotetext{
${ }^{50}$ Lawrence, 142.

${ }^{51}$ Jussi Hanhimäki and Odd Arne Westad, eds. The Cold War: A History in Documents and Eyewitness Accounts (Oxford University Press, 2003), 303.
} 
continue to act as a "nuclear umbrella" when requested. ${ }^{52}$ The Nixon Doctrine, sometimes referred to as Vietnamization, gave the United States a way out of Vietnam that showed to the world that the United States did all they could to help the South Vietnamese: the honourable exit Nixon was searching for. The Nixon Doctrine not only helped to set the United States on track to finally withdraw from Vietnam, but it also set a precedent for future involvement in the Third World during the Cold War, so that the United States was no longer required to intervene militarily in future conflicts. However, the United States continued to use their economic and diplomatic power to influence the Third World.

Alongside Détente, during the 1960s and 1970s, the peace protests and anti-war movement began to sweep across American society. Dissent against the United States government reached new heights. American citizens began to criticize their government on the political and military decisions being made with respect to the Vietnam War. The Vietnam War shocked the American public, and, as the war progressed, this dissent only got worse, especially after the Tet Offensive in 1968, when the North Vietnamese offensive showed the world what the communists in North and South Vietnam were capable of strategically. ${ }^{53}$ Vietnam War critics, such as Robert F. Kennedy and Senator Eugene McCarthy, gained a following and presented the anti-war movement to American politicians for them to support and advocate the end the Vietnam War. ${ }^{54}$ Civil rights leaders, such as Malcolm X, even became involved in the anti-war movement, advocating

\footnotetext{
${ }^{52}$ Richard Nixon, "The Nixon Doctrine Speech, 1969" in America in Vietnam: A Documentary History, eds. William Appleman Williams et al (Garden City, NY: Anchor Press, 1985), 282.

${ }^{53}$ Earle Wheeler to Lyndon B. Johnson, "Memorandum of February 27, 1968" in America in Vietnam: A Documentary History, eds. William Appleman Williams et al (Garden City, NY: Anchor Press/Doubleday, 1985), 269.

${ }^{54}$ Robert F. Kennedy, "RFK Calls Vietnam an Unwinnable War (Feb. 8, 1968)," in Vietnam Documents: American and Vietnamese Views of the War, ed. George N. Katsiaficas (London: M.E. Sharpe, 1992$), 90$.
} 
the end of the Vietnam War and global peace. ${ }^{55}$ The pinnacle of the anti-war movement occurred following the shooting at Kent State University on 4 May 1970, where the National Guard opened fire into a crowd of anti-war student protesters, killing four students and wounding nine others. ${ }^{56}$ The Kent State protests had occurred as a result of the Nixon Administration authorizing the military invasion of Cambodia on 30 April 30 $1970 .^{57}$ The Kent State killings sparked outrage across the nation and subsequently led to a major increase in the anti-war protests across American university and college campuses. ${ }^{58}$ The anti-war protests did not solely involve students, but also Vietnam War veterans who took to the streets to protest their discontent with the war in Vietnam. In terms of the impact on the Cold War, the anti-war movement had a tremendous impact on the Cold War atmosphere. The anti-war movement affected nations across the globe, specifically West Germany and its Free University. ${ }^{59}$ The protest against the United States government over their involvement in Vietnam directly led to Détente and the Nixon administration's efforts to finally put an end to the Vietnam War. Nixon needed to respond to the public dissent with direct action if he was to be successfully re-elected in the upcoming 1972 Presidential Election. The global anti-war movement directly influenced American foreign policy and, with the creation of Détente, influenced the remainder of the Cold War. The anti-war protests during the Vietnam War set a precedent for public objection and protest by the America public for future generations to follow when the people disagreed with their government's policies.

\footnotetext{
${ }^{55}$ George N. Katsiaficas, Vietnam Documents: American and Vietnamese Views of the War (London: M.E. Sharpe, 1992), 120.

${ }^{56}$ Williams et al, 289.

${ }^{57}$ Ibid, 283.

58 Ibid, 291.

${ }^{59}$ Jeremi Suri, “The Cultural Contradictions of Cold War Education: The Case of West Berlin," Cold War History 4, no. 3 (2004): 5.
} 
The formal end of the Vietnam War began in 1973 with the Paris Peace Accords, which was an agreement that laid out the procedure in which the United States was to follow for withdrawal from Vietnam and the agreement for the release of the American prisoners of war held in North Vietnam. ${ }^{60}$ Following President Nixon's resignation after the Watergate Scandal, President Gerald Ford took office. President Ford was tasked with removing the remainder of the American troops from Vietnam. From 1973 to 1975, the Vietnam War continued with American bombings of North Vietnam, but the United States significantly reduced the amount American troops in South Vietnam. ${ }^{61}$ The Vietnamization had been implemented, and the South Vietnamese were left to defend themselves against the attacks of the North Vietnamese, with a very small amount of American officials left in Saigon. Finally, on 29 April 1975, the evacuation of Saigon began, and the last Americans in Vietnam were evacuated via helicopter from the roof of the American embassy. South Vietnam fell to the North, and the Vietnam War was over. ${ }^{62}$ Even though the Vietnam War had come to an end, the United States supported anti-government factions in Cambodia into the 1980s and upheld a very strict trade embargo with Vietnam until $1994 .^{63}$ The United States had been defeated as nations across the globe witnessed the humiliating American evacuation from Saigon.

Throughout the Vietnam War, the United States government, until President Nixon, subscribed to the monolithic view of communism. This was the underlying cause for failure in Vietnam. The United States government did not understand the culture of Vietnam or the social, political, and nationalistic desires of the Vietnamese people. They

\footnotetext{
${ }^{60}$ Lawrence, 162.

${ }^{61}$ Ibid, 163.

${ }^{62}$ Ibid, 167.

${ }^{63}$ Craig Lockard, "Meeting Yesterday Head-on: The Vietnam War in Vietnamese, American, and World History," Journal of World History 5, no. 2 (1994): 230.
} 
were completely ignorant of the power that nationalism held. ${ }^{64}$ The motivation that nationalism brought to the Vietnamese people allowed them fight and die for their country. The United States underestimated the strength and resolve of the Vietnamese. Under-Secretary of State George W. Ball believed that Americans had contempt for the Vietnamese enemy. He claimed that the Vietnamese, who were considered to be unsophisticated, poorly equipped, peasant farmers would stand no chance against the might and power of the United States military. Ball claimed that the Vietnamese were not motivated by deep convictions like the Americans were. ${ }^{65}$ It is clear from George W. Ball's opinion that the United States government vastly underestimated the Vietnamese, and, as a result, suffered the same fate that the French colonial forces suffered two decades earlier. An aphorism by George Santayana perfectly summarizes the United States' involvement in Vietnam: "Those who refuse to learn from history are doomed to repeat it. ${ }^{, 66}$ The lack of synergy and cooperation between the civilian and military leaders of the United States also heavily contributed to their defeat in Vietnam. ${ }^{67}$ Similarly, the United States failed to adapt to the guerrilla style of warfare that the North Vietnamese were employing. The Vietnam War was fought on a terrain that rendered the traditional styles of warfare useless ${ }^{68}$ The Vietnamese had lived on that land for centuries and had an incredible advantage that the United States was never able to master. Along with guerrilla warfare came the question asked by Kennedy, "How can we tell if we are

\footnotetext{
${ }^{64}$ McNamara, In Retrospect, 321.

${ }^{65}$ Gettleman, 62.

${ }^{66}$ Ibid, 63.

${ }^{67}$ Robert Buzzanco, Masters of War: Military Dissent and Politics in the Vietnam Era (New York: Cambridge University Press, 1997), 216.

${ }^{68}$ George C. Herring, “America and Vietnam: The Unending War," Foreign Affairs 70, no. 5 (1991): 112.
} 
winning?" ${ }^{99}$ There was no way for the United States to evaluate their success in the war with no physical front for the war; there were no battle lines in the jungle. The United States military attempted to measure their progress in Vietnam by using statistics such as enemies killed, number of weapons seized, and prisoners taken but these were often erroneous and held no real significance in determining whether the Americans were "winning" or not. ${ }^{70}$ The view that Communism was all encompassing and homogeneous, the gross ignorance about the desire for self-determination held by the Vietnamese people, and the inability of the United States military to wage limited, guerrilla warfare were the major reasons why the all-powerful United States could not win a war against Vietnamese farmers.

In conclusion, the Vietnam War can be considered the most influential Cold War conflict. The changes that occurred to United States foreign policy throughout the Vietnam War had drastic effects on the Cold War atmosphere. In all aspects the Vietnam War was the quintessential Cold War conflict. It included proxy war between the United States and the Soviet Union, it had the potential to escalate into nuclear war, it resulted in the diplomatic recognition of the People's Republic of China, it led to arms reduction treaties between the major superpowers, and brought diplomacy to the forefront of Cold War strategy. The Vietnam War impacted the Cold War by generating change in American foreign policy, consequently altering the Cold War atmosphere, and by creating dissent across the globe against the United States government for their role in the Vietnam War. Out of all the critical events that occurred during the Cold War era, the

\footnotetext{
${ }^{69}$ Ibid, 112.

${ }^{70} \mathrm{McNamara}$, In Retrospect, 48.
} 
conflict between a hegemonic global superpower and a poverty-stricken society of farmers turned out to have the biggest influence on the Cold War. 


\section{Bibliography}

Buzzanco, Robert. Masters of War: Military Dissent and Politics in the Vietnam Era. Cambridge: Cambridge University Press, 1997.

Ellsberg, Daniel. Secrets: A Memoir of Vietnam and the Pentagon Papers. New York: Viking Press, 2002.

Gettleman, Marvin E. Vietnam: History, Documents and Opinions on a Major World Crisis. Greenwich, CT: Fawcett Pub, 1965.

Hanhimäki, Jussi and Odd Arne Westad, eds. The Cold War: A History in Documents and Eyewitness Accounts. London: Oxford University Press, 2003.

Hanhimäki, Jussi. "Conservative Goals, Revolutionary Outcomes: The Paradox of Detente." Cold War History 8, no. 4 (2008): 503-512.

Herring, George C. "America and Vietnam: The Unending War." Foreign Affairs 70, no. 5 (1991): 104-119.

Judge, Edward H., and John W. Langdon. The Cold War: A History Through Documents. Upper Saddle River, NJ: Prentice Hall, 1999.

Katsiaficas, George N. Vietnam Documents: American and Vietnamese Views of the War. Armonk, NY: M.E. Sharpe, 1992.

Kolko, Gabriel. Anatomy of a War: Vietnam, the United States, and the Modern Historical Experience. New York: Pantheon Books, 1985.

Lawrence, Mark Atwood. The Vietnam War: A Concise International History. New York: Oxford University Press, 2008.

Lockard, Craig. "Meeting Yesterday Head-on: The Vietnam War in Vietnamese, American, and World History." Journal of World History 5, no. 2 (1994): 227270.

McNamara, Robert S., and Brian VanDeMark. In Retrospect: The Tragedy and Lessons of Vietnam. New York: Vintage Books, 1996.

Suri, Jeremi, "The Cultural Contradictions of Cold War Education: The Case of West Berlin." Cold War History 4, no. 3 (April 2004): 1-20.

Williams, William Appleman et al, eds. America in Vietnam: A Documentary History. Garden City, NY: Anchor Press, 1985. 